\title{
NUMERICAL SIMULATION OF START CONTROL AND FINAL OBSERVATION IN FLUID FILTRATION MODEL
}

\author{
K.V.Perevozhikova ${ }^{1}$, perevozchikovakv@susu.ru, \\ N. A. Manakova ${ }^{1}$, manakovana@susu.ru. \\ ${ }^{1}$ South Ural State University, Chelyabinsk, Russian Federation
}

\begin{abstract}
The article is devoted to the model to regulate the velocity potential of the free surface of the filtering fluid. This model is based on the problem on start control and final observation by weak generalized solutions of a fluid filtration model, which belongs to the class of mathematical models based on semi-linear Sobolev-type equations with $p$ coercive and $s$-monotone operators. We find the sufficient conditions under which there exists a solution to the problem on start control and final observation of the model under study. An algorithm for the numerical solution method is constructed and a computational experiment is presented.
\end{abstract}

Keywords: Sobolev type equation; fluid filtration model; problem on start control and final observation; mathematical modelling; decomposition method.

\section{Introduction}

Currently, many modern studies are developed at the intersection of different fields of science. For example, in engineering, economic and physical objects, various processes are investigated using mathematical modelling. In order to characterize modelling briefly, we note replacing a real system (process, phenomenon) with a model that is in some correspondence with the real system and is able to reproduce the properties or characteristics of the real system. Therefore, mathematical modelling plays important role in science, in the research of engineering, economic objects and systems. Also, note that conducting production experiments requires a lot of financial, time and labor costs. Sometimes, conducting full-scale experiments is impossible due to a number of reasons, for example, it is not possible to control individual parameters (temperature, pressure, course of processes, or other factors). Therefore, creation and study of mathematical models describing these processes are of great applied importance. In this case, as a rule, finding an analytical solution is impossible, as a result of which it becomes necessary to create numerical methods for finding approximate solutions to initial-boundary value problems for such models.

In most cases, for various physical processes, it is possible not only to implement numerical modelling, but also to control the components of the system in which this process takes place. It is assumed that, at any moment of time, any dynamical system (that is, a system that develops in a certain way and evolves in time) can be in one of a certain (finite or infinite) number of possible states. In this case, control is understood as an impact that can change the current state, as well as the subsequent development of the system. In this regard, there exists a question about finding the best (optimal) control to the process. The development of computational methods for solving optimal control problems is associated with the optimality conditions and traditionally uses standard constructions, approximations and variation procedures obtained within the framework 
of the qualitative theory. As classical works in the theory of optimal control, we note works written by J.-L. Lions and A.V. Fursikov. For example, the work [1] systematically studies optimal control problems for partial differential equations. In other papers (see, for example, [2]), the existence of boundary control was shown for parabolic and hyperbolic systems. Boundary control is characterized by finding boundary control functions that transfer the system from a given initial state to a given final state in a fixed time interval $T$. Boundary control is most often used for the problems on rod vibration and heat (mass) transfer. The methods described by J.-L. Lions were applied to the study of various physical processes [3,4]. The work of A.V. Fursikov [5] shows the existence of a solution to the control problem for models described by the Navier-Stokes and Euler equations. Note that these systems belong to non-classical nonlinear models of mathematical physics. Another type of optimal control is the problem on start control and final observation. This problem is widely studied for various processes. For example, the work [6] obtains sufficient conditions for the solvability of the problem on start control and final observation for one abstract quasilinear Sobolev-type equation in a weak generalized sense, and also proves the solvability of the problem on start control and final observation for the Barenblatt Gilman model. The work [7] presents analytical and numerical studies of the problems on start control and final observation by solutions to one class of Sobolev-type equations with the Showalter - Sidorov condition. The paper [8] investigates start control and final observation by solutions to the Dirichlet - Showalter - Sidorov problem for the degenerate system of Fitz Hugh - Nagumo equations.

In the classical theory of groundwater movement, one of the basic equations is the Boussinesq filtration equation

$$
\frac{\partial h}{\partial t}=\gamma \frac{\partial}{\partial x}\left((H(x, y)+h) \frac{\partial h}{\partial x}\right)+\gamma \frac{\partial}{\partial y}\left((H(x, y)+h) \frac{\partial h}{\partial y}\right), \quad \gamma=\frac{k p g}{\mu m}
$$

where the function $H(x, y)$ characterizes the underlying surface without breaks and fractures, the function $h(x, y)$ describes the groundwater surface, the parameter $p$ characterizes the pressure, $k$ is the permeability coefficient, which depends on the properties of the medium only, $g$ is the acceleration of gravity, $m$ is the porosity of the medium, $\mu$ is the dynamic viscosity (see Fig. 1).

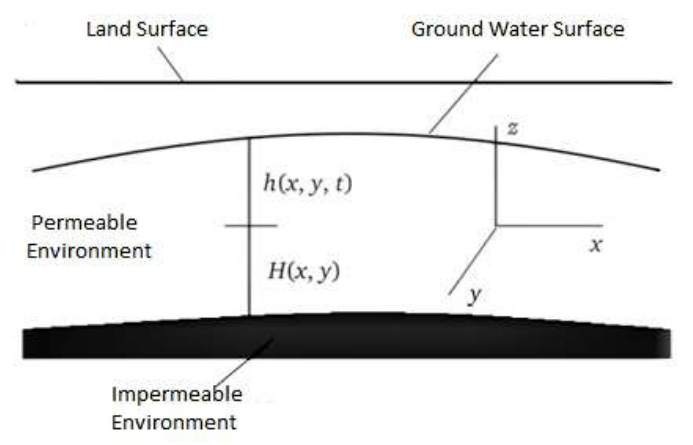

Fig. 1. Groundwater movement

The work [9] shows that when studying a fluid filtration model based on this equation, the vertical component of the velocity of the filtration fluid free surface movement is not 
taken into account, and this fact can lead to errors in calculations in particular cases. In 1972, the work [10] presented the derivation of the equation

$$
\frac{\partial h_{0}}{\partial t}=\frac{k \bar{h}_{0}}{\mu}\left[\frac{\partial}{\partial x}\left(\frac{\partial h_{0}}{\partial x}-\frac{\bar{h}_{0}^{2}}{6 \beta^{2}} \frac{\partial^{3} h_{0}}{\partial x^{3}}\right)+\frac{\mu \bar{h}_{0}}{2 \beta^{2} k} \frac{\partial^{3} h_{0}}{\partial x^{2} \partial t}\right]+\frac{\varepsilon_{0}+\varepsilon_{\alpha}}{\mu} \beta
$$

where the function $h_{0}$ is a head at the base of the layer, the parameter $\bar{h}_{0}$ is a head averaged over $t$ and $x, \varepsilon_{0}, \varepsilon_{\alpha}$ are modules for feeding the flow through its base and free surface, respectively, $\mu$ is the coefficient of free porosity. If we neglect the third derivatives in this equation, then we get the Boussinesq equation. This generalized equation takes into account all possible phenomena and characteristics of fluid filtration. The work [11] obtains the following particular form of the generalized Boussinesq equation:

$$
(\lambda-\Delta) x_{t}=a \Delta\left(|x|^{p-2} x\right)+y, \quad p \geq 2,
$$

under the assumption that, from the physical point of view, the function $u=u(x, t)$ is the potential of the filtering fluid velocity, the parameters $a \in \mathbb{R}_{+}, \lambda \in \mathbb{R}$ haracterize the medium, and the parameter $\lambda$ can take negative values.

Many papers are devoted to the study of the solvability of initial-boundary value problems for equation (1). For example, in [12], the existence and uniqueness of a solution to the first boundary value problem for equation (1) is proved. In [13], a study of the phase space is given. In the paper [14], the authors consider equation (1) with a nonlinear nonsubordinate non-monotonic source and prove the comparison principle for solutions to the first initial-boundary value problem. The work [15] presents an algorithm for the numerical solution of initial-boundary value problems for the generalized Boussinesq equation, which describe the motion of a free surface of a fluid filtering in a layer of finite depth.

The purpose of this work is a numerical study of a mathematical model for regulating the potential of velocity of the filtering fluid free surface. The model is based on the problem on start control and final observation

$$
J(x(T), u)=\vartheta\left\|x(T)-x_{f}\right\|_{L_{p}(\Omega)}^{p}+(1-\vartheta)\|u\|_{L_{p}(\Omega)}^{p} \rightarrow \inf , \quad \vartheta \in(0,1)
$$

by weak generalized solutions to the mathematical model of fluid filtration, which is based on Sobolev-type equation (1) with the Showalter - Sidorov initial condition

$$
(\lambda-\Delta)(x(s, 0)-u(s))=0, \quad s \in \Omega
$$

and the Dirichlet boundary condition

$$
x(s, t)=0, \quad(s, t) \in \partial \Omega \times \mathbb{R}_{+} .
$$

In the considered problem on start control and final observation, $J(x(T), u)$ is a target functional; $u \in \mathfrak{U}_{a d}, \mathfrak{U}_{a d}$ is a closed and convex set in the control space $\mathfrak{U}$, the function $x_{f}=x_{f}(s)$ is the required state of the system, which must be achieved with a minimal initial action after the time $t=T$.

The problem on start control and final observation simulates the situation, when the moment of result observation is separated in time from the initial impact, i.e. control. In the case of a nonlinear equation of state, the search for the start control is difficult. One of approaches to solve this problem is the decomposition method $[2,16]$. This method allows 
to linearize the original equation and to transfer the entire phenomenon of nonlinearity to the functional, which largely simplifies the numerical scheme for finding an approximate solution to the problem on start control and final observation. Also, note that the optimal control problem for a fluid filtration model was studied in [17] by the descent method. In our case, the problem on start control and final observation simulates the process of initial regulation of the potential of the filtering fluid free surface velocity in order to achieve the required dynamics with the lowest control costs at a given moment of time.

Also, note that equation (2) belongs to the class of semi-linear Sobolev-type equations with $p$-coercive and $s$-monotone operator. Moreover, the $p$-coercive operator is strongly coercive, and the $s$-monotone operator is strongly monotone. The unique solvability of problem (1), (3), (4) was obtained by G.A. Sviridyuk [13]. In [18], it was shown that the phase space of the problem is a simple smooth Banach manifold.

In this work, in order to construct and implement a numerical study of the problem on start control and final observation for a mathematical model of fluid filtration, we use a projection method based on the Galerkin method [19]. The application of the method to the study of problems on stability of hydrodynamic flows was realized by G.I. Petrov [20], who proved the convergence of the Galerkin method for finding the eigenvalues of a wide class of equations including equations for non-conservative systems such as, for example, the equations of oscillations in a viscous fluid. For the first time, for semi-linear Sobolev type equations, this method was considered by G.A. Sviridyuk and T.G. Sukacheva [21]. In the case of degenerate models, the projection method [17] is often used in order to find approximate solutions. This method allows to take into account the phenomenon of degeneracy of equations by choosing a basis from the eigenfunctions of the main operator.

\section{Numerical Solution of Problem on Start Control and Final Observation}

The purpose of this paper is to study a mathematical model to control the distribution of the potentials of a filtration fluid velocity. The model is based on the problem on start control and final observation (2) by weak generalized solutions to the mathematical model of the distribution of a filtration fluid velocity. The latter model is based on Sobolev-type equation (1) with the Showalter - Sidorov initial condition (3) and the Dirichlet boundary condition (4). To this end, consider the existence of weak generalized solutions to the mathematical model of the distribution of the filtering fluid velocity. For this purpose, consider the function spaces $\mathcal{H}=W_{2}^{-1}(\Omega), \mathfrak{H}=L_{2}(\Omega), \mathfrak{B}=L_{p}(\Omega)$ defined in the domain $\Omega \subset \mathbb{R}^{n}$. Note that, for $p \geq \frac{2 n}{n+2}$, there exists a dense and continuous embedding $\stackrel{\circ}{W} \underset{2}{1}(\Omega) \hookrightarrow L_{q}(\Omega)$, therefore $L_{p}(\Omega) \hookrightarrow W_{2}^{-1}(\Omega)$, where $\frac{1}{p}+\frac{1}{q}=1$. In $\mathcal{H}$ define the scalar product by the formula

$$
\langle x, y\rangle=\int_{\Omega} x \tilde{y} d s \quad \forall x, y \in \mathcal{H},
$$

where $\tilde{y}=(\Delta)^{-1} y$ is a generalized solution to the homogeneous Dirichlet problem for the Laplace operator in the domain $\Omega$. Let $\mathfrak{B}^{*}=\left(L_{p}(\Omega)\right)^{*}$ and $\mathfrak{H}^{*}=\left(L_{2}(\Omega)\right)^{*}$, where $\left(L_{p}(\Omega)\right)^{*}$ is the dual with respect to duality space $(5)$. Hence, $\mathfrak{H}^{*}$ and $\mathfrak{B}^{*}$ are dense and continuous 
embeddings

$$
\mathfrak{B} \hookrightarrow \mathfrak{H} \hookrightarrow \mathcal{H} \hookrightarrow \mathfrak{H}^{*} \hookrightarrow \mathfrak{B}^{*} .
$$

The fluid filtration model belongs to the class of models based on semi-linear Sobolevtype equations with $p$-coercive and $s$-monotone operator. In general terms, this model was studied in [17]. In order to study the solvability of problem $(3)$, (4) for equation (1), it is necessary to reduce the problem to the Showalter - Sidorov problem

$$
L(x(s, 0)-u(s))=0
$$

for the abstract semi-linear Sobolev type equation

$$
L \dot{x}+M(x)=y, \quad \text { ker } L \neq\{0\} .
$$

To this end, we define the operators $L$ and $M$ :

$$
\begin{aligned}
& \langle L x, y\rangle=\int_{\Omega}(\lambda x \tilde{y}+x y) d s, \quad x, y \in \mathfrak{H} ; \\
& \langle M(x), y\rangle=\int_{\Omega}|x|^{p-2} x y d s, \quad x, y \in \mathfrak{B} .
\end{aligned}
$$

Further, in order to prove the existence of a solution, we need to determine the properties of the operators $L$ and $M$. To this end, we need to choose a special basis from the eigenfunctions of the operator $(-\Delta):-\Delta \varphi_{k}=\lambda_{k} \varphi_{k}, \varphi_{k} \in \stackrel{\circ}{W_{2}^{1}}(\Omega)$. Also, note that $\tilde{\varphi}_{k}=(-\Delta)^{-1} \varphi_{k}=\frac{\varphi_{k}}{\lambda_{k}}$. The work [17] proves the following lemma on the properties of the operators $L$ and $M$.

Lemma 1. [17] (i) For all $\lambda \geq-\lambda_{1}$, the operator $L \in \mathcal{L}\left(\mathfrak{N}, \mathfrak{N}^{*}\right)$ is self-adjoint, Fredholm and non-negative defined.

(ii) For any $a \in \mathbb{R}_{+}$, the operator $M \in C^{1}\left(\mathfrak{B}, \mathfrak{B}^{*}\right)$ is $s$-monotonous and $p$-coercive.

If $\lambda \geq-\lambda_{1}$

$$
\text { ker } L=\left\{\begin{array}{c}
\{0\}, \text { if } \lambda>-\lambda_{1} \\
\operatorname{span}\left\{\varphi_{1}\right\}, \text { if } \lambda=-\lambda_{1}
\end{array}\right.
$$

Therefore

$$
\operatorname{coim} L=\{x \in \mathfrak{N}: \quad\langle x, \varphi>=0 \quad \forall \varphi \in \operatorname{ker} L \backslash\{0\}\} .
$$

Construct the space

$$
\mathfrak{X}=\left\{x \mid x \in L_{\infty}(0, T ; \operatorname{coim} L) \cap L_{p}(0, T ; \mathfrak{B})\right\}
$$

and the set

$$
\mathfrak{M}=\left\{\begin{array}{c}
\mathfrak{B}, \text { if } \lambda>-\lambda_{1} \\
\left\{x \in \mathfrak{B}: \int_{\Omega}|x|^{p-2} x \varphi_{1} d s=\int_{\Omega} \tilde{y} \varphi_{1} d s\right\}, \text { if } \lambda=-\lambda_{1} .
\end{array}\right.
$$

Using the projection method, we represent approximate solutions to problem (1), (3), (4) in the form of Galerkin sums

$$
x_{m}(s, t)=\sum_{i=1}^{m} a_{i}(t) \varphi_{i}(s), \quad m>\operatorname{dim} \operatorname{ker} L,
$$


where the coefficients $a_{i}=a_{i}(t), i=1, \ldots, m$, are determined by the system of equations

$$
\int_{\Omega}\left(\lambda x_{t} \tilde{\varphi}_{i}+x_{t} \varphi_{i}+a|x|^{p-2} x \varphi_{i}\right) d s=\int_{\Omega} y \tilde{\varphi}_{i} d s, \quad i=1, \ldots, m,
$$

and the conditions

$$
\int_{\Omega}\left[\lambda\left(x_{m}(s, 0)-u(s)\right) \tilde{\varphi}_{i}(s)+\left(x_{m}(s, 0)-u(s)\right) \varphi_{i}(s)\right] d s=0, \quad i=1, . ., m .
$$

Equations (9) represent a degenerate system of differential equations. Before proceeding to the theorem on the existence of a solution, we note that by a weak generalized solution to Showalter - Sidorov problem (1), (3), (4) we mean the vector-function $x \in \mathfrak{X}$ for $T \in \mathbb{R}_{+}$, if the function satisfies

$$
\begin{gathered}
\int_{0}^{T}<L \frac{d x}{d t}+M(x), \zeta>\varphi(t) d t=\int_{0}^{T}<y, \zeta>\varphi(t) d t, \zeta \in \mathfrak{B}, \varphi \in L_{2}(0, T), \\
<L(x(0)-u), \zeta>=0 \text { for almost all } t \in(0, T) .
\end{gathered}
$$

In the work [17], the following theorem on the existence of a unique weak generalized solution to problem (1), (3), (4) was proved.

Theorem 1. [17] Let $p \geq \frac{2 n}{n+2}$ and $\lambda \geq-\lambda_{1}$. Then, for any $u \in \mathfrak{B}$ and $y \in L_{q}\left(0, T ; \mathfrak{B}^{*}\right)$, there exists a unique weak generalized solution $x \in \mathfrak{X}$ to problem (1), (3), (4).

This theorem is proved using the phase space method and the monotonicity method, which requires to construct a priori estimates. That is, using the Banach-Alaoglu theorem and passing to the weak limit, it is proved that the desired solution is found. Also, note that Theorem 1 shows the convergence of Galerkin approximations (8) to a weak generalized solution to problem (1), (3), (4).

Next, we turn to the study of a mathematical model to control the distribution of the potentials of the filtering fluid velocity. In order to show the existence of a solution to mathematical model $(1)-(4)$, we construct the control space $\mathfrak{U}=\mathfrak{B}$ and choose $\mathfrak{U}_{a d} \subset \mathfrak{U}$ to be nonempty, closed, convex set. Also, note that by a solution to problem (1) - (4) we mean a pair of functions $(\tilde{x}(T), \tilde{u})$ that satisfies the following condition:

$$
J(\tilde{x}(T), \tilde{u})=\inf _{(x(T), u)} J(x(T), u),
$$

where the pairs $(\tilde{x}, \tilde{u}) \in \mathfrak{X} \times \mathfrak{U}_{a d}$ satisfy problem (1), (3), (4) in the weak generalized case.

Remark 1. The set of admissible pair $\mathfrak{A}$ of problem $(1)-(4)$ is a pair $(x, u)$ satisfying problem (1), (3), (4), for which

$$
J(x, u)<+\infty .
$$

If $\mathfrak{U}_{a d}=\varnothing$, then, for any $u \in \mathfrak{U}_{a d} \subset \mathfrak{U}$, the set of admissible pairs $(x, u)$ is not empty.

After introducing all the necessary definitions and spaces, we consider the theorem on the existence of a solution to control the distribution of the potentials of the filtering fluid velocity. To this end, consider the following theorem. 
Theorem 2. Let $p \geq \frac{2 n}{n+2}$ and $\lambda \geq-\lambda_{1}$. Then, for any $y \in L_{q}\left(0, T ; \mathfrak{B}^{*}\right)$, there exists a solution $(\tilde{x}(T), \tilde{u})$ to problem $(1)-(4)$.

Proof.

The proof is based on the theory of $s$-monotone and $p$-coercive operators and can be represented by the following steps.

1. Since the set of admissible pairs $\mathfrak{A}$ is not empty, there exists a sequence $\left\{x_{m}(T), u_{m}\right\} \in \mathfrak{B} \times \mathfrak{U}$ such that

$$
\lim _{m \rightarrow \infty} J\left(x_{m}(T), u_{m}\right)=\inf _{(x(T), u)} J(x(T), u),
$$

then it follows from (1) that

$$
\left\|u_{m}\right\|_{\mathfrak{B}} \leq \text { const, } \forall m \in \mathbb{N} \text {. }
$$

From (11) (consider a subsequence if necessary), we choose a weakly converging sequence $u_{m} \rightarrow \tilde{u}$ in $\mathfrak{B}$. According to the Mazur theorem, the point $\tilde{u} \in \mathfrak{U}_{a d}$. Let $x_{m}=x\left(u_{m}\right)$ be a weakly generalized solution to problem

$$
\begin{gathered}
L \frac{d}{d t} x_{m}+M\left(x_{m}\right)=y \\
L\left(x_{m}(0)-u_{m}\right)=0 .
\end{gathered}
$$

Multiply equation $(12)$ by $x_{m}(t)$ and integrate over $(0, t)$, we have

$$
\begin{aligned}
& \int_{0}^{t} d \tau \int_{\Omega}\left((\lambda-\Delta) x_{m \tau} \tilde{x}_{m}+\left|x_{m}\right|^{p-2} x_{m}^{2}\right) d s=\int_{0}^{t} d \tau \int_{\Omega} y \tilde{x}_{m} d s, \\
& \left|x_{m}(t)\right|^{2}+C_{1} \int_{0}^{t}\left\|x_{m}(\tau)\right\|_{\mathfrak{B}}^{p} d \tau \leq C_{2} \int_{0}^{t}\|y(\tau)\|_{\mathfrak{B}^{*}}^{q} d \tau+\left|u_{m}\right|^{2},
\end{aligned}
$$

where $|x|^{2}$ is norm in coim $L$, which is induced from the subspace $\mathcal{H}$. By virtue of the conditions of Theorem 1, we can find a subsequence such that

$$
\begin{gathered}
x_{m} \rightarrow x * \text {-weak in } L_{\infty}(0, T ; \operatorname{coim} L) ; \\
x_{m} \rightarrow \tilde{x} \text { weak in } L_{p}(0, T ; \mathfrak{B}) \\
M\left(x_{m}\right) \rightarrow \mu \text { weak in } L_{q}\left(0, T ; \mathfrak{B}^{*}\right) .
\end{gathered}
$$

Since the operator $M$ is $p$-coercive, we have

$$
\int_{0}^{T}\left\langle M\left(x_{m}\right), x_{m}\right\rangle d \tau \leq \int_{0}^{T}\left\|M\left(x_{m}\right)\right\|_{\mathfrak{B}^{*}}\left\|x_{m}\right\|_{\mathfrak{B}} d \tau \leq C^{M} \int_{0}^{T}\left\|x_{m}\right\|_{\mathfrak{B}}^{p-1}\left\|x_{m}\right\|_{\mathfrak{B}} d \tau,
$$

and hence the operators $M\left(x_{m}\right)$ are bounded in $L_{q}\left(0, T ; \mathfrak{B}^{*}\right)$. Since the functional is coercive, we obtain the boundedness of the sequences

$$
\left\|x_{m}\right\|_{L_{p}(0, T ; \mathfrak{B})} \leq \mathrm{const} \text { for all } m \in \mathbb{N} .
$$


2. Passing to the limit in the equation and using compactness and monotonicity methods, we obtain that the weak limit sequences $\left\{x_{m}\right\},\left\{u_{m}\right\}$ satisfy the equation of state

$$
L \frac{d \tilde{x}}{d t}+\mu=y, \quad L(\tilde{x}(0)-\tilde{u})=0
$$

for all $m \in \mathbb{N}$. From the estimates above (possibly, passing to a sequence), we select weakly converging sequences in the corresponding spaces $x_{m} \rightarrow \tilde{x}, u_{m} \rightarrow \tilde{u}, L \frac{d x_{m}}{d t} \rightarrow L \frac{d \tilde{x}}{d t}$. According to the Mazur theorem, the point $u \in \mathfrak{U}_{a d}$. The proof is similar to the proof given in [16].

3. The proof of the equality $M\left(x_{m}\right)=\mu$ is based on the method of monotonicity in consequence of $s$-monotonicity of the operators $M[2]$.

4. Then $\tilde{x}=\tilde{x}(\tilde{u})$ and $\liminf J\left(u_{m}\right) \geq J(\tilde{u})$. Hence, $\tilde{u}$ is a start control to problem (1)-(4). The proof is similar to the proof given in [16].

Theorem 1 and Theorem 2 establish the existence of a solution, but do not describe a method to find the solution. The equation of state is understood as a means to set explicitly the dependence of the system state function on control. We apply the decomposition method, which allows to proceed to the consideration of an equivalent problem, in which the original equation of state is reduced to the system of linear equations by introducing the additional vector-function $x(s, t)=v(s, t)$ [1]. Next, we apply the penalty method complementing the decomposition method by introducing an additional term and the penalty parameter $r_{\varepsilon}=\frac{1}{\varepsilon} \rightarrow+\infty$ for $\varepsilon \rightarrow 0+$, which allows tend $x$ to $v$, into the functional. Then problem $(1)-(4)$ is equivalent to the following problem:

$$
\begin{gathered}
L \dot{x}+M(v)=y, \quad x(u, v)=v, \\
L(x(0)-u)=0, \\
J_{\theta}^{\varepsilon}(x(T), v(T), u)=\theta \cdot \vartheta\left\|x(T)-x_{f}\right\|_{\mathfrak{B}}^{p}+ \\
+(1-\theta) \cdot \vartheta\left\|v(T)-x_{f}\right\|_{\mathfrak{B}}^{p}+\|u\|_{\mathfrak{B}}^{p}+ \\
+(1-\vartheta) \int_{0}^{T} r_{\varepsilon}\|x-v\|_{\mathcal{H}}^{2} d t \rightarrow \inf , \quad \theta, \vartheta \in(0,1),
\end{gathered}
$$

where the penalty parameter $r_{\varepsilon} \rightarrow+\infty$ if $\varepsilon \rightarrow+0$.

Also, note that by a solution to the obtained problem we mean a triple $(\tilde{x}(T), \tilde{v}(T), \tilde{u}) \in \mathfrak{B} \times \mathfrak{B} \times \mathfrak{U}_{a d}$ if

$$
J_{\theta}^{\varepsilon}(\tilde{x}(T), \tilde{v}(T), \tilde{u})=\inf _{(x(T), v(T), u)} J_{\theta}^{\varepsilon}(x(T), v(T), u)
$$

where the triple $(x, v, u) \in \mathfrak{X} \times \mathfrak{X} \times \mathfrak{U}_{a d}$ satisfies (8), (9) in the weak generalized case.

Theorem 3. Let $p \geq \frac{2 n}{n+2}$ and $\lambda \geq-\lambda_{1}$. Then, for any $y \in L_{q}\left(0, T ; \mathfrak{B}^{*}\right)$, there exists a solution $\left(x_{\varepsilon}, v_{\varepsilon}, u_{\varepsilon}\right)$ to problem (8) - (10), moreover $u_{\varepsilon} \rightarrow \tilde{u}, x_{\varepsilon}(T) \rightarrow \tilde{x}(T)$ for $\varepsilon \rightarrow+0$. Proof.

Due to the reduction of problem (1), (3), (4) to problem (6), (7), this theorem is a consequence of [17, Th. 3]. 


\section{Algorithm of the Numerical Method to Find the Start Control and Final Observation}

Based on the theoretical results obtained in the previous paragraphs, we develop an algorithm to find an approximate solution to the problem on start control and final observation for the mathematical model of fluid filtration on the basis of the modified decomposition method and the Ritz method. Let $\sigma$ be a spectrum of the operator $(-\Delta)$ with the homogeneous Dirichlet condition, $\left\{\lambda_{k}\right\}$ be a set of the eigenvalues numbered in non-decreasing order and $\left\{\varphi_{k}\right\}$ be a family of the corresponding eigenfunctions, which are orthonormalized with respect to the scalar product $\langle\cdot, \cdot\rangle$ in $W_{2}^{-1}(\Omega)$. Next, we search for an approximate solution to control problem (1) - (4) using the decomposition method and the penalty method described in [16]. Applying the penalty method, we proceed to consideration of control problem $(8)-(10)$, where the proximity of the approximate solutions $\tilde{x}$ and $\tilde{v}$ is achieved by introducing a new functional of the form (10), where the penalty parameter is $r_{\varepsilon} \rightarrow+\infty$ at $\varepsilon \rightarrow 0+$. Using the projection method, an approximate solution $\tilde{x}, \tilde{v}, \tilde{u}$ to control problem (8) - (10) is searched in the form

$$
\tilde{x}(s, t)=\sum_{k=2}^{m} a_{k}(t) \frac{\varphi_{k}(s)}{\lambda_{k}}, \quad \tilde{u}(s)=\sum_{k=2}^{m} u_{k} \frac{\varphi_{k}(s)}{\lambda_{k}}, \quad \tilde{v}(s, t)=\sum_{i=2}^{m} v_{k}(t) \frac{\varphi_{k}(s)}{\lambda_{k}}
$$

where $m \in \mathbb{N}$ is such that $m>l$, and $l=\operatorname{dim} \operatorname{ker} L$, in order to take into account the effects of the degenerate equation. The algorithm for the numerical study of the problem on start control and final observation is presented in the block diagram (Fig. 2). On the basis of the algorithm, we implement a program for the numerical study of the problem on start control and final observation for the fluid filtration model. The program includes the following steps.

Step 1. Enter parameters of the equation, parameters of the domain, number of terms in the approximate solution, eigenfunctions and eigenvalues of the homogeneous Dirichlet problem for the operator $(-\Delta)$.

Step 2. Form an approximate solution and control in the form of Galerkin sums (11) using the program cycle "for()" from 1 to $m$.

Step 3. Substitute the approximate solution into the equation using the procedure subs. Step 4. Multiply the resulting solution by the eigenfunctions $\varphi_{k}(s)$, integrate from 0 to $l$, and, as a result, generate a system of algebraic-differential equations. Next, check the equations for the degeneracy or non-degeneracy, that is, whether $\lambda$ is an eigenvalue of the operator $(-\Delta)$ based on the procedure "if()".

Step 5. Find a solution to the system of algebraic-differential equations with initial conditions using the procedure "dsolve( $)$ " with respect to the unknowns $a_{k}(t)$.

Step 6. Generate the quality functional using the procedure "subs()". Approximate the unknown control components using polynomials.

Step 7. Using the package "Optimization" and the procedure "NPLSolve()", find a minimum of the functional and the corresponding system state.

Step 8. Display the resulting solution and plot a graph.

Step 9. Construct an approximate solution to the Showalter - Sidorov problem with the found initial distribution $u(s)$ and compare the results. 


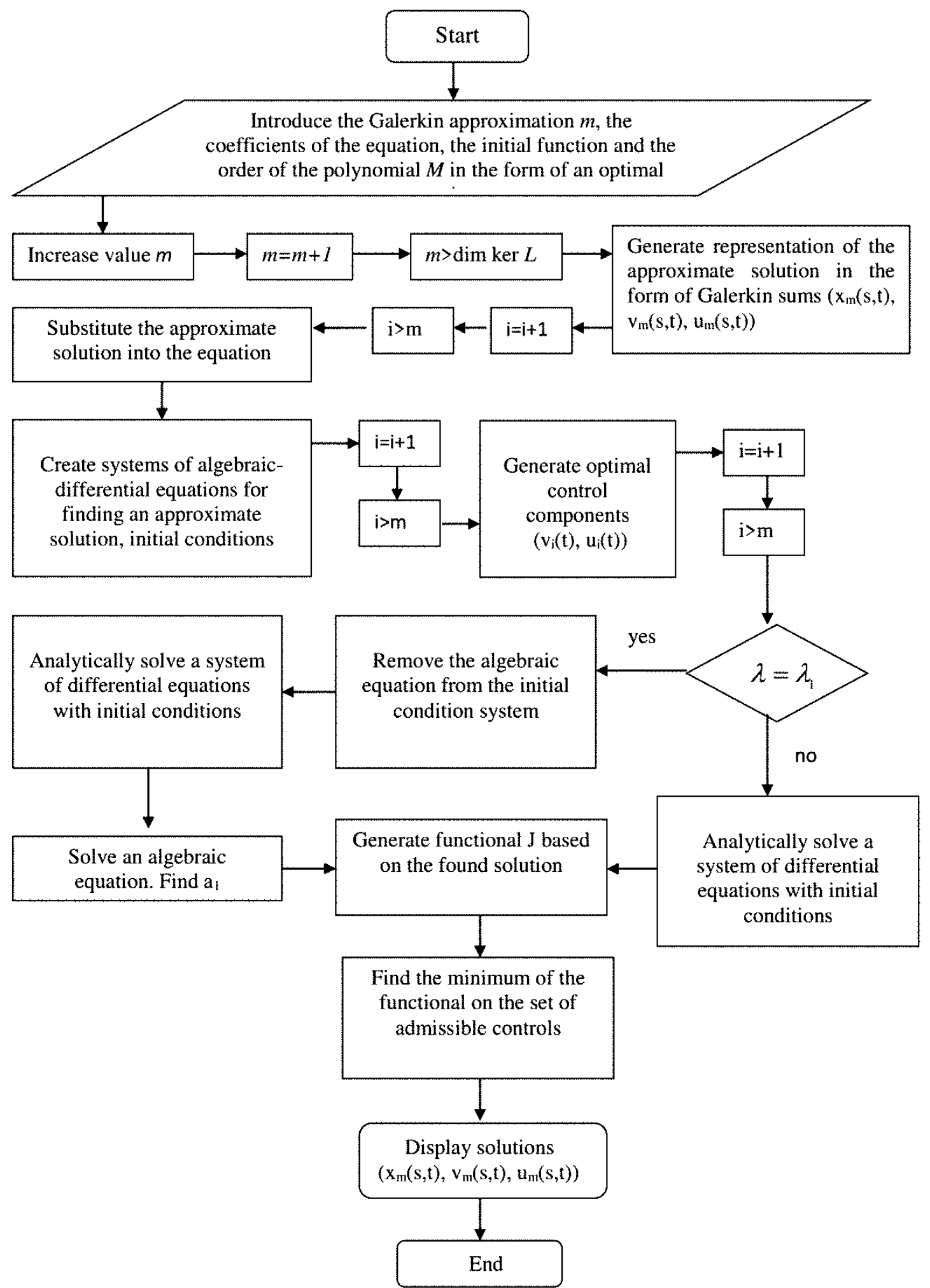

Fig. 2. Algorithm for the numerical study of the problem on start control and final observation 
The result of the program "Numerical research of the mathematical model of liquid filtration" can be illustrated by the following example.

Example 1. The problem is to find an approximate solution to the problem of start control and final observation of the problem (1) - (4) for $\lambda=-1 ; a=5 ; p=4 ; y=0$; $\Omega=(0, \pi) ; T=\frac{7}{10} ; \theta=\frac{21}{55}, \beta=\frac{99}{100} ; \varepsilon=\frac{1}{100} ; N=3 ; x_{f}=\frac{\sqrt{2}}{3 \sqrt{\pi}}(\sin s+\sin 2 s)$. Consider the equivalent to the problem of starting control and final observation:

$$
\begin{gathered}
J(x(T), v(T), u)=\frac{21}{55} \cdot \frac{99}{100} \int_{0}^{\pi}\left|x(s, T)-\frac{\sqrt{2}}{3 \sqrt{\pi}} \sin s\right|^{4} d s+ \\
+\left(1-\frac{21}{55}\right) \cdot \frac{99}{100} \int_{0}^{\pi}\left|v(s, T)-\frac{\sqrt{2}}{3 \sqrt{\pi}} \sin s\right|^{4} d s+\left(1-\frac{99}{100}\right) \int_{0}^{\pi}|u(s)|^{2} d s+ \\
+\frac{1}{100} \int_{0}^{T} d t \int_{0}^{\pi}(x(s, t)-v(s, t))\left((-\Delta)^{-1}(x(s, t)-v(s, t))\right) d s \rightarrow \inf
\end{gathered}
$$

for Showalter - Sidorov - Dirichlet problem (3), (4) for equation (1). The eigenvalues and functions are as follows:

$$
\varphi_{k}(s)=\sqrt{\frac{2}{\pi}} \sin k s, \lambda_{k}=k^{2}, k=1,2, \ldots,
$$

moreover $(-\Delta)^{-1} \varphi_{k}=\frac{\varphi_{k}}{\lambda_{k}}$. Based on the projection method, an approximate solution to the problem is represented $\tilde{x}(s, t), \tilde{v}(s, t), \tilde{u}(s)$ in the form of sums (11).

The results work of the program "Numerical research of the mathematical model of liquid filtration" calculations are control coefficients such that the value of the functional $J=0.07731823$, and the approximate solution of the problem

$$
\begin{gathered}
\tilde{v}(s, t)=\sqrt{\frac{2}{\pi}} \sin s\left(0.20393817 t^{2}-6.32325001 t-2.28086711\right)+ \\
+\sqrt{\frac{2}{\pi}} \sin 2 s\left(1.0054557076732367 t^{2}-1.0061574125401362 t+0.3493954249337957\right)+ \\
\quad+\sqrt{\frac{2}{\pi}} \sin 3 s\left(5.38036216 t^{2}-1.44814874 t-1.91471859\right), \\
\tilde{x}(s, t)=\frac{9}{4 \sqrt{\pi^{3}}}\left(\sqrt { 2 } \operatorname { s i n } \pi \left(2.583317223 t^{2}-2.8765272 t+9.58210015 t^{6}+1.55939443 t^{3}-\right.\right. \\
\left.\quad-2.61106796 t^{5}-8.69387704 t^{4}-2.95449818\right)+ \\
-9.22084854 e^{\frac{2 t}{3}} t^{2}+2.76625456 e^{\frac{2 t}{3}} t+2.04907742 e^{\frac{2 t}{3}} t^{3}-3.41513049 e^{\frac{2 t}{3}} t^{4}+ \\
\left.+4.55409505 e^{\frac{2 t}{3}} t^{5}+4.14938184\right)-\frac{1}{4 \sqrt{\pi^{3}}}\left(e^{\frac{-t}{4}} \sqrt{2} \sin 3 s(-7.65887437 \pi-\right. \\
-2.97559853 e^{\frac{-t}{4}}+7.43899632 e^{\frac{-t}{4}} t-9.29874541 t^{2}+7.74895450 e^{\frac{-t}{4}} t^{3}- \\
\left.-4.84309669 e^{\frac{-t}{4}} t^{4}-1.00757889 e^{\frac{-t}{4}} t^{6}+2.42159179 e^{\frac{-t}{4}} t^{5}+2.97559853\right),
\end{gathered}
$$




$$
\tilde{u}(s)=\sqrt{\frac{2}{\pi}}(0.34939542 \sin s-0.8401354 \sin 2 s+0.01320449 \sin 3 s) .
$$

The graphs of the approximate solution of the problem (1) - (4) are shown in Fig. 3 and Fig. 4. Let us compare the obtained functions $\tilde{x}(s, T), \tilde{v}(s, T)$ with the required state $x_{d}(s)$. The graph of these functions at time $T=0.7$ is shown in the Fig. 5 . The difference between the required functions $\tilde{x}(s, t)$ and $\tilde{v}(s, t)$ is small:

$$
\Delta=\left(\int_{0}^{T}\left(\int_{0}^{\pi}|\tilde{x}(s, t)-\tilde{v}(s, t)|^{4} d s\right) d t\right)^{\frac{1}{4}}=0.02978542743 .
$$

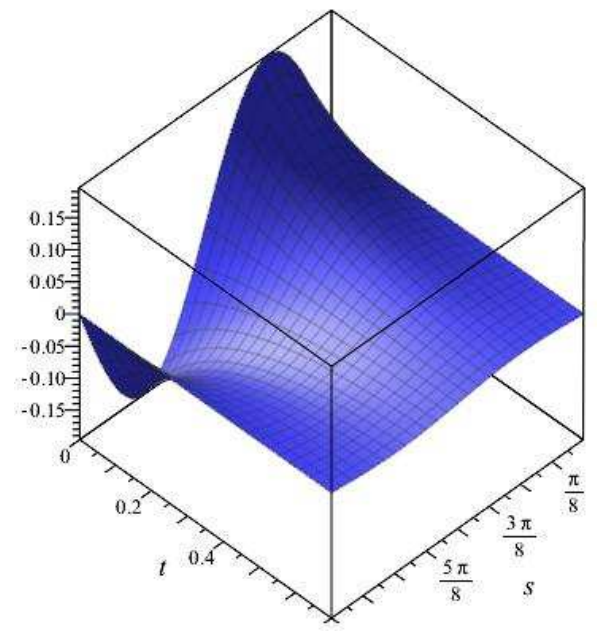

a) Graph of $\tilde{x}(s, t)$

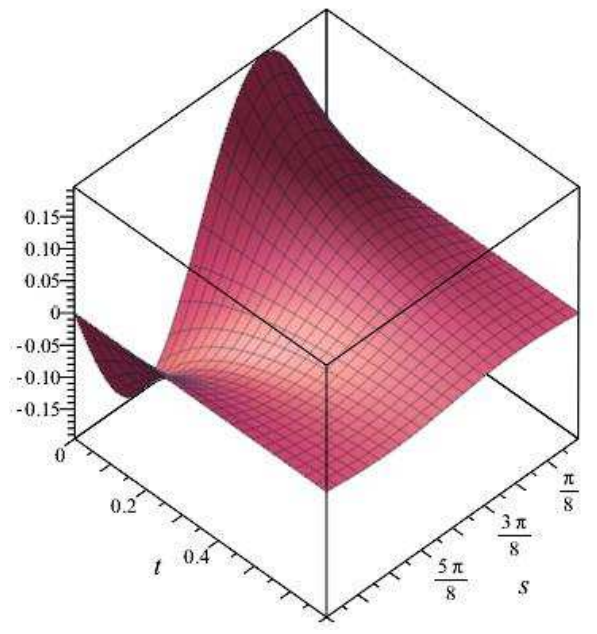

b) Graph of $\tilde{v}(s, t)$

Fig. 3. The approximate solution to the problem (1) - (4)

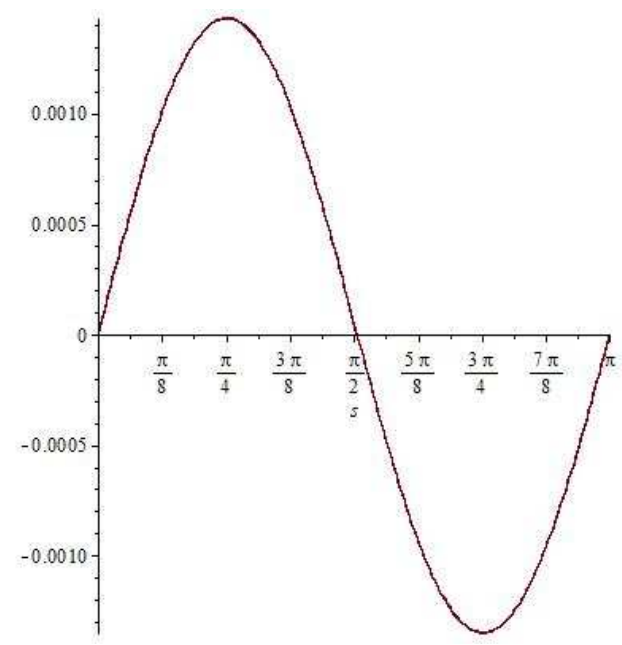

Fig. 4. An initial state of the system $u(s)$

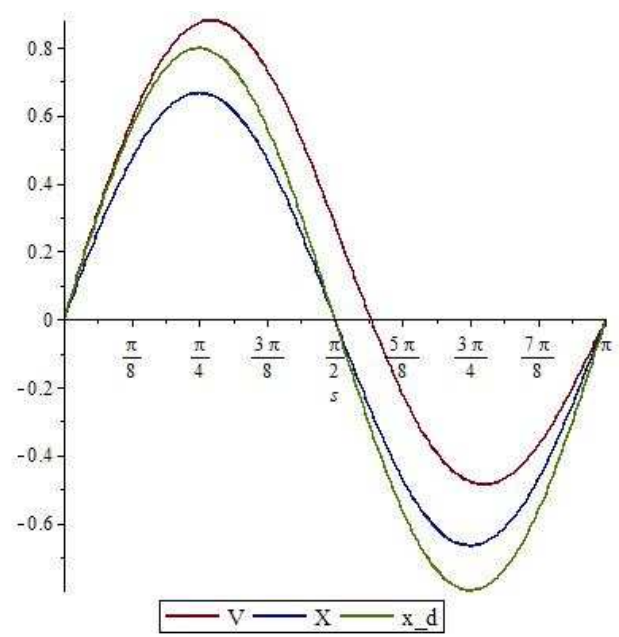

Fig. 5. Graph of functions $\tilde{x}(s ; 0,7), \tilde{v}(s ; 0,7), x_{d}(s), s \in(0, \pi)$

This work was funded by RFBR and Chelyabinsk Region, project number 20-41-000001. 


\section{References}

1. Lions J.-L. Some Questions in the Optimal Control of Distributed Systems. Russian Mathematical Surveys, 1985, vol. 40, no. 4, pp. 57-72. DOI: 10.1070/RM1985v040n04ABEH003612

2. Lions J.-L. Controle Optimal de Systemes Gouvernes par des Equations aux Daerivaes Partielles. Paris, Dunod, 1968. (in French)

3. Fayazova Z. K. Boundary Control of the Heat Transfer Process in the Space. Izv. Vyssh. Uchebn. Zaved. Mat., 2019, no. 12, pp. 82-90. (in Russian). DOI: 10.26907/0021-34462019-12-82-90

4. Moiseev E. I., Kholomeyeva A. A., Frolov A. A. Boundary Displacement Control for the Oscillation Process with Boundary Conditions of Damping Type for a Time Less than Critical. Itogi Nauki i Tekhniki. Ser. Sovrem. Mat. Pril. Temat. Obz., 2019, vol. 160, pp. 74-84. (in Russian)

5. Fursikov A. V. Control Problems and Theorems Concerning the Unique Solvability of a Mixed Boundary Value Problem for the Three-Dimensional Navier - Stokes and Euler Equations. Mathematics of the USSR-Sbornik, 1982, vol. 43, no. 2, pp. 251-273. DOI: $10.1070 / \mathrm{SM} 1982 \mathrm{v} 043 \mathrm{n} 02 \mathrm{ABEH} 002447$

6. Bogatyreva E. A. The Start Control and Final Observation Problem for a Quasilinear Sobolev Type Equation. Bulletin of the South Ural State University. Series: Mathematics. Mechanics. Physics, 2015, vol. 7, no. 4, pp. 5-10. (in Russian). DOI: $10.14529 / \mathrm{mmph} 150401$

7. Manakova N. A., Vasiuchkova K. V. Research of One Mathematical Model of the Distribution of Potentials in a Crystalline Semiconductor. Bulletin of the South Ural State University. Series: Mathematical Modelling, Programming and Computer Software, 2019, vol. 12, no. 2, pp. 150-157. DOI: 10.14529/mmp190213

8. Gavrilova O. V. Start Control and Final Observation Problem for the Fitz Hugh Nagumo System for the Dirichlet - Showalter - Sidorov Condition. Bulletin of the South Ural State University Series: Mathematics. Mechanics. Physics, 2018, vol. 10, no. 3, pp. 12-18. DOI: $10.14529 / \mathrm{mmph} 180302$

9. Polubarinova-Kochina P. Y. Theory of Ground Water Movement. Princeton, New Jersey, Princeton University Press, 1962.

10. Dzektser E. S. Generalization of the Equation of Motion of Ground Waters with Free Surface. Dokl. Akad. Nauk SSSR, 1972, vol. 202, no. 5, pp. 1031-1033. (in Russian)

11. Furaev V. Z., Shadrin G. A. Derivation of the Equation for the Free Surface of the Filtered Liquid in a Layer of Finite Depth. Calculate. Mathematics and Mathematical Physics, 1982, vol. 10, pp. 66-71. (in Russian)

12. Furaev V. Z. Solvability in the Large of the First Boundary Value Problem for the Generalized Boussinesq Equation. Differ. Uravn., 1983, vol. 19, no. 11, pp. 20142015. (in Russian) 
13. Sviridyuk G. A. A Problem for the Generalized Boussinesq Filtration Equation. Soviet Mathematics (Izvestiya VUZ. Matematika), 1989, vol. 33, no. 2, pp. 62-73. (in Russian)

14. Kozhanov A. I. An Initial-Boundary Value Problem for Equations of the Generalized Boussinesq Equation Type with a Nonlinear Source. Mathematical Notes, 1999, vol. 65, no. 1, pp. 59-63. DOI: $10.4213 / \operatorname{mzm} 1029$

15. Furaev V. Z., Antonenko A. I. Approximation of Solutions to the Boundary Value Problems for the Generalized Boussinesq Equation. Bulletin of the South Ural State University. Series: Mathematical Modelling, Programming and Computer Software, 2017, vol. 10, no. 4, pp. 145-150. DOI: $10.14529 / \mathrm{mmp} 170414$

16. Manakova N. A. Method of Decomposition in the Optimal Control Problem for Semilinear Sobolev Type Models. Bulletin of the South Ural State University. Series: Mathematical Modelling, Programming and Computer Software, 2015, vol. 8, no. 2, pp. 133-137. (in Russian). DOI: 10.14529/mmp150212

17. Manakova N. A. Mathematical Models and Optimal Control of The Filtration and Deformation Processes. Bulletin of the South Ural State University. Series: Mathematical Modelling, Programming and Computer Software, 2015, vol. 8, no. 3, pp. 5-24. (in Russian). DOI: 10.14529/mmp150301

18. Sviridyuk G. A., Kliment'ev M. V. Phase Space for Sobolev Type Equations with s-Monotone and Strongly Coercive Operators. Russian Mathematics (Izvestiya VUZ. Matematika), 1994, vol. 38, no. 11, pp. 72-79.

19. Galerkin B. On the Equilibrium of Elastic Plate, Bounded by the Isosceles Rectangular Triangle. J. Soc. Phys.-Math. Leningrade, 1926, vol. 1, issue 1, pp. 89-101.

20. Petrov G. I. Application of the Galerkin Method to the Problem of the Stability of Viscous Fluid. Journal of Applied Mathematics and Mechanics, 1940, vol. 4, pp. 1-13. (in Russian)

21. Sviridyuk G. A., Sukacheva T. G. Galerkin Approximations of Singular Nonlinear Equations of Sobolev Type. Soviet Mathematics (Izvestiya VUZ. Matematika), 1989, vol. 33 , no. 10 , pp. $56-59$.

Ksenia V. Perevozchikova, Postgraduate Student at the Department of Equations of Mathematical Physics, South Ural State University (Chelyabinsk, Russian Federation), perevozchikovakv@susu.ru.

Natalia A. Manakova, DSc (Math), Docent, Professor at the Department of Equations of Mathematical Physics, South Ural State University (Chelyabinsk, Russian Federation), manakovana@susu.ru.

Received January 11, 2021. 


\title{
ЧИСЛЕННОЕ МОДЕЛИРОВАНИЕ СТАРТОВОГО УПРАВЛЕНИЯ И ФИНАЛЬНОГО НАБЛЮДЕНИЯ В МОДЕЛИ ФИЛЬТРАЦИИ ЖИДКОСТИ
}

\author{
К. В. Перевозчикова, Н. А. Манакова
}

\begin{abstract}
Статья посвящена численному исследованию модели регулирования потенциала скорости свободной поверхности фильтрующейся жидкости. Данная модель основана на задаче стартового управления и финального наблюдения слабыми обобщенными решениями модели фильтрации жидкости, которая относится к классу математических моделей, основанных на полулинейных уравнениях соболевского типа с $p$ коэрцитивным и $s$-монотонным операторами. Найдены достаточные условия существования решения задачи стартового управления и финального наблюдения исследуемой модели. Построен алгоритм численного метода решения и приведен вычислительный эксперимент.

Ключевые слова: уравнения соболевского типа; модель фильтрации жидкости; задача стартового управления и финального наблюдения; математическое моделирование; метод декомпозиции.
\end{abstract}

\section{Литература}

1. Лионс, Ж. Л. Некоторые вопросы оптимального управления распределенными системами / Ж. Л. Лионс // Успехи математических наук. - 1985. - Т. 40, № 4 (244). - C. 55-68.

2. Lions, J.-L. Controle Optimal de Systemes Gouvernes par des Equations aux Daerivaes Partielles / J.-L. Lions. - Paris: Dunod, 1968.

3. Фаязова, 3. К. Граничное управление процессом теплообмена в пространстве 3. К. Фаязова // Известия вузов. Математика. - 2019. - № 12. - С. 82-90.

4. Моисеев, Е. И. Граничное управление смещением процессом колебаний при граничном условии типа торможения за время, меньшее критического / Е. И. Моисеев, А. А. Холомеева, А. А. Фролов // Итоги науки и техники. Серия: Современная математика и ее приложения. Тематические обзоры. - 2019. - Т. 160. - С. 74-84.

5. Фурсиков, А. В. Задачи управления и теоремы, касающиеся однозначной разрешимости смешанной краевой задачи для трехмерных уравнений Навье - Стокса и Эйлера / А. В. Фурсиков // Математический сборник. - 1981. - Т. 115 (157), № 2 (6). - C. 281-306.

6. Богатырева, Е. А. Задача стартового управления и финального наблюдения для одного квазилинейного уравнения соболевского типа / Е. А. Богатырева // Вестник ЮУрГУ. Серия: Математика. Механика. Физика. - 2015. - Т. 7, № 4. - С. 5-10.

7. Манакова Н. А. Исследование одной математической модели распределения потенциалов в кристаллическом полупроводнике / Н. А. Манакова, К. В. Васючкова // Вестник ЮУрГУ. Серия: Математическое моделирование и программирование. - 2015. - Т. 8, № 3. - С. 5-24. 
8. Гаврилова, О. В. Задача стартового управления и финального наблюдения для системы уравнений Фитц Хью - Нагумо с условием Дирихле - Шоуолтера - Сидорова / О. В. Гаврилова // Вестник ЮУрГУ. Серия: Математика. Механика. Физика. - 2018. - Т. 10, № 3. - С. 12-18.

9. Полубаринова-Кочина, П. Я. Теория движения грунтовых вод П. Я. Полубаринова-Кочина. - М.: Наука, 1977.

10. Дзекцер, Е. С. Обобщение уравнения движения грунтовых вод со свободной поверхностью / Е. С. Дзекцер // Доклад Академии наук СССР. - 1972. - Т. 202, № 5. - C. 1031-1033.

11. Фураев, В. З. Вывод уравнения для свободной поверхности фильтрующейся жидкости в слое конечной глубины / В. З. Фураев, Г. А. Шадрин // Вычислительная математика и математическая физика. - 1982. - Т. 10. - С. 66-71.

12. Фураев, В. З. О разрешимости в целом первой краевой задачи для обобщенного уравнения Буссинеска / В. З. Фураев // Дифференциальные уравнения. - 1983. T. 19, № 11. - C. 2014-2015.

13. Свиридюк, Г. А. Одна задача для обобщенного фильтрационного уравнения Буссинеска / Г. А. Свиридюк / / Известия вузов. Математика. - 1989. - № 2. - С. 55-61.

14. Кожанов, А. И. Начально-краевая задача для уравнений типа обобщенного уравнения Буссинеска с нелинейным источником / А. И. Кожанов // Математические заметки. - 1999. - Т. 65, вып. 1. - С. 70-75.

15. Фураев, В. З. Аппроксимация решений краевых задач для обобщенного уравнения Буссинеска / В. З. Фураев, В. И. Антоненко // Вестник ЮУрГУ. Серия: Математическое моделирование и программирование. - 2017. - Т. 10, № 4. C. $145-150$.

16. Манакова, Н .А. Метод декомпозиции в задаче оптимального управления для полулинейных моделей соболевского типа / Н. А. Манакова // Вестник ЮУрГУ. Серия: Математическое моделирование и программирование. - 2015. - Т. 8, № 2. C. $133-137$.

17. Манакова Н. А. Математические модели и оптимальное управление процессами фильтрации и деформации / Н. А. Манакова // Вестник ЮУрГУ. Серия: Математическое моделирование и программирование. - 2015. - Т. 8, № 3. - С. 5-24.

18. Свиридюк, Г. А. Фазовые пространства уравнений типа Соболева с $s$ монотонными и сильно коэрцитивными операторами / Г. А. Свиридюк, М. В. Климентьев // Известия вузов. Математика. - 1994. - № 11. - Р. 75-82.

19. Galerkin, B. On the Equilibrium of Elastic Plate, Bounded by the Isosceles Rectangular Triangle / B. Galerkin // Жуурн. Лен. физ.-мат. общ. - 1926. - Т. 1, вып. 1. - P. 89-101. 
20. Петров, Г. И. Применение метода Галеркина к задаче об устойчивости течения вязкой жидкости / Г. И. Петров // Прикладная математика и механика. - 1940. T. 4. - C. 1-13.

21. Свиридюк, Г. А. О галеркинских приближениях сингулярных нелинейных уравнений типа Соболева / Г. А. Свиридюк, Т. Г. Сукачева // Известия вузов. Математика. - 1989. - № 10. - С. 44-47.

Перевозчикова Ксения Владимировна, аспирант кафедры уравнений математической физики, Южно-Уральский государственный университет (г. Челябинск, Российская Федерачия), ретеvozchikovakv@susu.ru.

Манакова Наталья Александровна, доктор физико-математических наук, дочент, профессор кафедры уравнений математической физики, ЮжноУральский государственный университет (г. Челябинск, Российская Федераиия), manakovana@susu.ru.

Поступила в редакцию 11 января 2021 г. 